\title{
Upaya Pencegahan Kehamilan Risiko Tinggi yang Disebabkan “4 Terlalu" pada Wanita Usia Subur di Desa Juntiweden Kabupaten Indramayu
}

\section{Prevention of High-Risk Pregnancy Prevention Caused by "4 Terlalu" in Fertile Women in Juntiweden Village, Indramayu Regency}

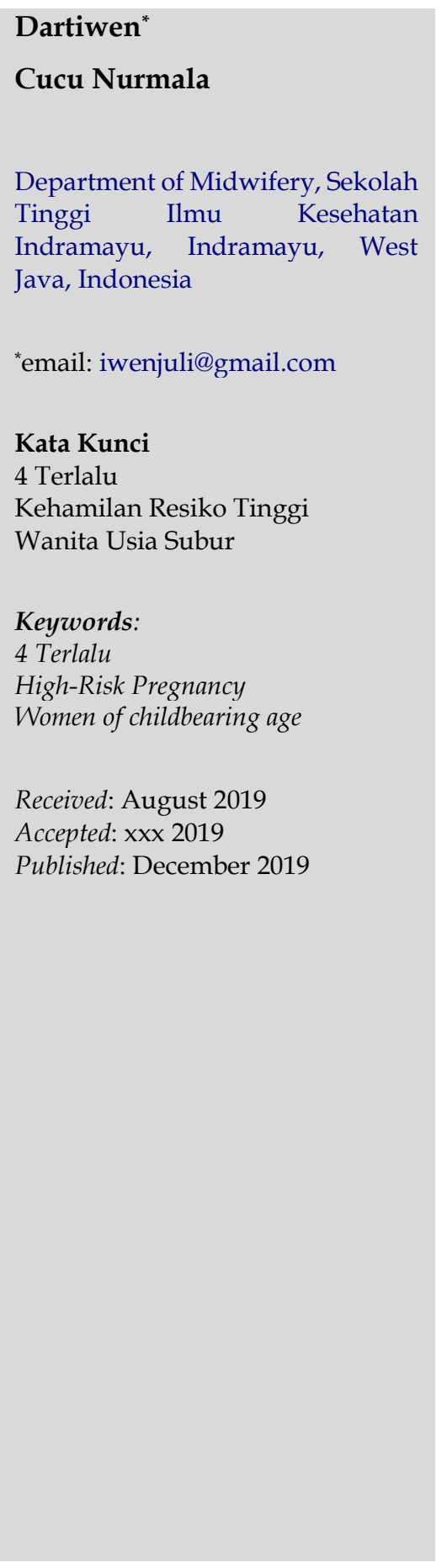

\begin{abstract}
Abstrak
Wanita Usia Subur (WUS) adalah wanita yang keadaan organ reproduksinya berfungsi dengan baik antara umur 20 - 45 tahun. Di Desa Juntiweden masih banyak ditemukan ibu hamil yang mempunyai risiko tinggi sehingga tenaga kesehatan perlu mengembangkan kemampuan praktis untuk meningkatkan kesehatan ibu. Salah satu pendekatan kami adalah melalui kegiatan pengabdian kepada masyarakat dengan melakukan penyuluhan kepada wanita usia subur yang bertujuan meningkatkan pengetahuan untuk mencegah kehamilan risiko tinggi yang disebabkan oleh " 4 Terlalu" sebagai upaya untuk meningkatkan kesehatan reproduksi perempuan. Metode penyuluhan menggunakan metode belajar orang dewasa diantaranya diskusi, tanya jawab serta pemutaran video. Uraian kegiatannya yaitu dilaksanakan pretest terlebih dahulu dengan menggunakan kuesioner, pemberian materi kemudian dilaksanakan postest. Hasilnya dari 50 orang jumlah peserta didapatkan bahwa sebelum dilakukan penyuluhan (pretest) terdapat 44 orang (88\%) dengan pengetahuan kurang dan 6 orang (12\%) dengan pengetahuan cukup, sedangkan setelah diberikan penyuluhan (postest) didapatkan hasil 50 orang $(100 \%)$ pengetahuannya baik. Hal ini berarti terdapat peningkatan pengetahuan WUS tentang pencegahan kehamilan risiko tinggi setelah mendapatkan penyuluhan. Kegiatan pengabdian ini dapat meningkatkan pengetahuan WUS dalam upaya pencegahan kehamilan risiko tinggi untuk mengurangi jumlah kematian ibu dan bayi yang disebabkan 4 Terlalu.
\end{abstract}

\begin{abstract}
Fertile Age Women (WUS) are women whose reproductive organs function well between the ages of 20 and 45 years. In Juntiweden Village, there are still many pregnant women who have a high risk so that health workers need to develop practical skills to improve maternal health. One of our approaches is through community service activities by counseling women of childbearing age who aim to increase knowledge to prevent high-risk pregnancies caused by " 4 Terlalu" as an effort to improve women's reproductive health. The counseling method uses adult learning methods, including discussion, question and answer, and video screenings. The description of the activity is carried out pretest in advance by using a questionnaire, giving material then carried out posttest. The results of the 50 people the number of participants found that before counseling (pretest) there were 44 people $(88 \%)$ with less knowledge and six people $(12 \%)$ with enough knowledge, whereas after being given counseling (posttest) results obtained 50 people $(100 \%)$ good knowledge. This means that there is an increase in WUS knowledge about preventing high-risk pregnancies after getting counseling. This dedication activity can increase the knowledge of WUS in efforts to prevent high-risk pregnancies from reducing the number of maternal and infant deaths caused by 4 Terlalu.
\end{abstract}




\section{PENDAHULUAN}

Data hasil Riset Kesehatan Dasar tahun 2010 yang telah dilaksanakan oleh Badan Penelitian dan Pengembangan Kesehatan menunjukkan bahwa permasalahan kesehatan pada perempuan berawal dari masih tingginya usia perkawinan pertama dibawah 20 tahun yaitu $5 \%$ pada usia $10-14$ tahun dan $42 \%$ pada usia $15-19$ tahun. Pada perempuan dengan umur pertama haid yang masih muda dan perkawinan dibawah umur membuat panjang rentang usia reproduksi perempuan dan berdampak pada banyaknya anak yang dilahirkan (Djamilah \& Kartikawati, 2014; Kamal, 2012). Secara nasional, dapat dilihat ada $8 \%$ perempuan 10-59 tahun melahirkan 5-6 anak serta 3\% melahirkan anak lebih dari 7.

Wanita Usia Subur (WUS) adalah wanita yang keadaan organ reproduksinya berfungsi dengan baik antara umur 20-45 tahun. Pada wanita usia subur ini berlangsung lebih cepat dari pada pria (Harianti \& Nurbaiti, 2016). Puncak kesuburan ada pada rentang usia 20-29 tahun. Pada usia ini wanita memiliki kesempatan $95 \%$ untuk hamil. pada usia 30 tahun persentasenya menurun hingga 90\% sedangkan memasuki usia 40 tahun kesempatan untuk hamil hingga menjadi $40 \%$ setelah usia 40 tahun hanya punya maksimal 10\% kesempatan untuk hamil (Wallach et al., 1986).

Kesehatan ibu sebagai bagian dari kesehatan masyarakat digambarkan meningkat jika terjadi penurunan Angka Kematian Ibu (AKI), meningkatnya pertolongan persalinan oleh tenaga kesehatan dimana persalinan tersebut terjadi di fasilitas kesehatan (Sumarmi, 2017; Sari et al., 2014). Data dari Dinas Kesehatan Kabupaten Indramayu tahun 2018, jumlah kematian ibu masih tinggi yaitu 65 kasus. Salah satu faktor yang berkaitan dengan risiko tinggi kehamilan ibu adalah usia ibu terlalu muda ( $<20$ tahun) dan terlalu tua $(>35$ tahun)
(Monita et al., 2015). Oleh karena itu, perlu dilakukan penundaan sementara untuk kehamilan atau perhatian khusus jika sudah terlanjur hamil maka untuk mencegah kehamilan risiko tinggi disebabkan 4 Terlalu kepada pasangan usia subur menjadi tantangan besar di masa mendatang bagi tenaga kesehatan (Putri et al., 2017; Nursal \& Satri, 2014).

Di Desa Juntiweden masih banyak ditemukan ibu hamil yang mempunyai risiko tinggi sehingga tenaga kesehatan perlu mengembangkan kemampuan praktis untuk meningkatkan kesehatan ibu. Salah satu pendekatan kami adalah melalui kegiatan pengabdian kepada masyarakat dengan penyuluhan kepada WUS yang bertujuan untuk meningkatkan pengetahuan untuk mencegah kehamilan risiko tinggi yang disebabkan oleh 4 Terlalu sebagai upaya untuk meningkatkan kesehatan reproduksi perempuan.

\section{METODOLOGI}

Tahap persiapan pada kegiatan ini adalah menyiapkan materi pokok penyuluhan tentang kehamilan risiko tinggi, membuat kuesioner yang terdiri dari beberapa pertanyaan sebagai alat evaluasi untuk menilai sejauh mana materi yang disampaikan dapat dimengerti dan dipahami WUS, serta mempersiapkan alat-alat lainnya untuk menunjang kegiatan penyuluhan seperti infokus, laptop dan buku KIA. Kegiatan dilaksanakan tanggal 21 Agustus 2017 mulai pukul 08.00 - 11.30 WIB bertempat di Balai Desa Juntiweden Kecamatan Juntinyuat Kabupaten Indramayu. Peserta adalah wanita usia subur sebanyak 50 orang. Metode penyuluhan menggunakan metode belajar orang dewasa diantaranya diskusi, tanya jawab dan pemutaran video. Adapun uraian kegiatan yang dilakukan yaitu pretest terlebih dahulu dengan menggunakan kuesioner, pemberian materi dan dilaksanakan postest kemudian data dianalisis dengan distribusi frekuensi. 


\section{HASIL DAN PEMBAHASAN}

Jumlah peserta sebanyak 50 orang dengan karakteristik umur ibu $<20$ tahun sebanyak 17 orang, 20-35 tahun sebanyak 22 orang dan umur $>35$ tahun sebanyak 11 orang. Pendidikan SD, SMP dan SMA, dari 50 orang WUS bekerja sebagai ibu rumah tangga. Jumlah pertanyaan pada kuesioner sebanyak 20 pertanyaan meliputi definisi, faktor - faktor yang mempengaruhi, tanda - tanda kehamilan risiko tinggi, penatalaksanaan dan upaya pencegahan kehamilan risiko tinggi. Adapun hasil pretest dan posttest dapat dilihat pada Tabel I dan II berikut:

Tabel I. Hasil Penilaian Pre-test

\begin{tabular}{|c|c|c|c|c|c|}
\hline \multicolumn{6}{|c|}{ Pengetahuan_PRE } \\
\hline & & Frequency & Percent & Valid Percent & $\begin{array}{c}\text { Cumulative } \\
\text { Percent }\end{array}$ \\
\hline \multirow[t]{3}{*}{ Valid } & Cukup & 6 & 12.0 & 12.0 & 12.0 \\
\hline & Kurang & 44 & 88.0 & 88.0 & 100.0 \\
\hline & Total & 50 & 100.0 & 100.0 & \\
\hline
\end{tabular}

Tabel II. Hasil Penilaian Post-test

\begin{tabular}{|c|r|r|r|r|}
\multicolumn{5}{c|}{ Pengetahuan_POST } \\
\hline & & & & Cumulative \\
& Frequency & Percent & /alid Percen & Percent \\
\hline Valid Baik & 50 & 100.0 & 100.0 & 100.0 \\
\hline
\end{tabular}

Dari tabel tersebut dapat dilihat bahwa sebelum dilakukan penyuluhan terdapat 44 orang $(88 \%)$ dengan hasil pengetahuan kurang dan 6 orang (12\%) dengan pengetahuan cukup, sedangkan setelah diberikan penyuluhan hasilnya 50 orang (100\%) pengetahuannya baik. Hal ini berarti terdapat peningkatan pengetahuan WUS tentang pencegahan kehamilan risiko tinggi setelah mendapatkan penyuluhan, artinya bahwa tujuan dari kegiatan ini memberikan pengetahuan tentang upaya pencegahan kehamilan risiko tinggi yang disebabkan 4 Terlalu guna untuk meningkatkan kesehatan reproduksi perempuan sangat efektif. Upaya ini dilakukan untuk deteksi dini oleh tenaga kesehatan tentang adanya faktor risiko dan komplikasi serta penanganan yang adekuat sedini mungkin pada wanita usia subur merupakan kunci keberhasilan dalam penurunan Angka Kematian Ibu dan Bayi yang dilahirkan (Ristrini \& Oktarina, 2014).

Kegiatan pengabdian masyarakat ini mendapat sambutan yang baik dari kepala desa, pamong dan warga, terlihat dari dukungan sarana dan prasarana yang telah disiapkan untuk mendukung kegiatan ini dan antusias peserta untuk mengikuti sampai akhir acara. Kegiatan ini ditutup dengan penandatanganan berita acara dan pemberian kenang-kenangan berupa alat-alat kebersihan dari STIKes Indramayu kepada warga Desa Juntiweden. Dokumentasi kegiatan Pengabdian yang dilakukan disajikan pada Gambar 1, 2, dan 3 berikut.

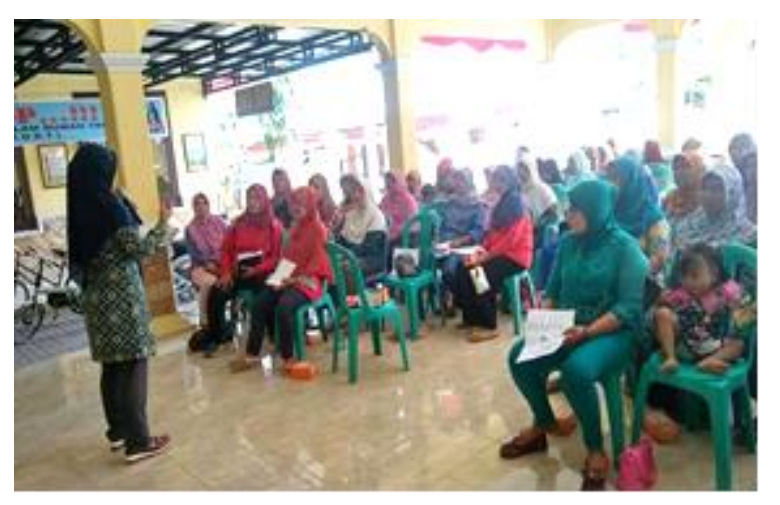

Gambar 1. Kegiatan pre-test

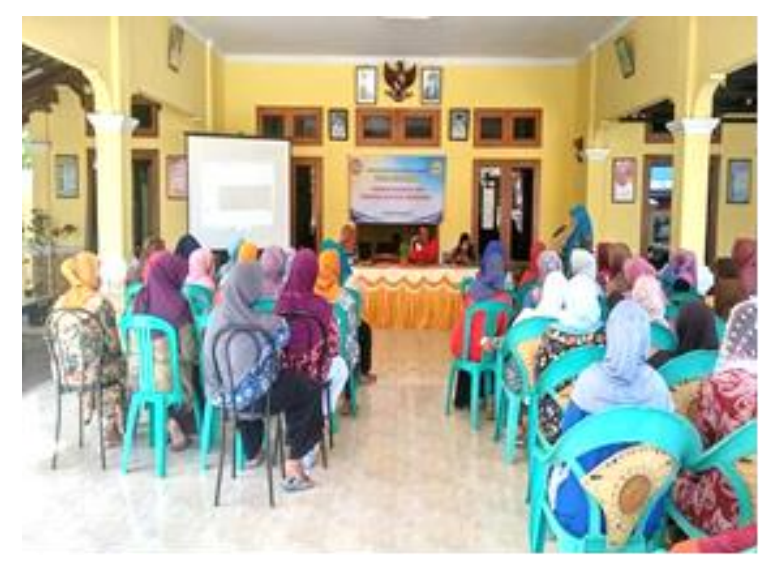

Gambar 2. Kegiatan penyuluhan 


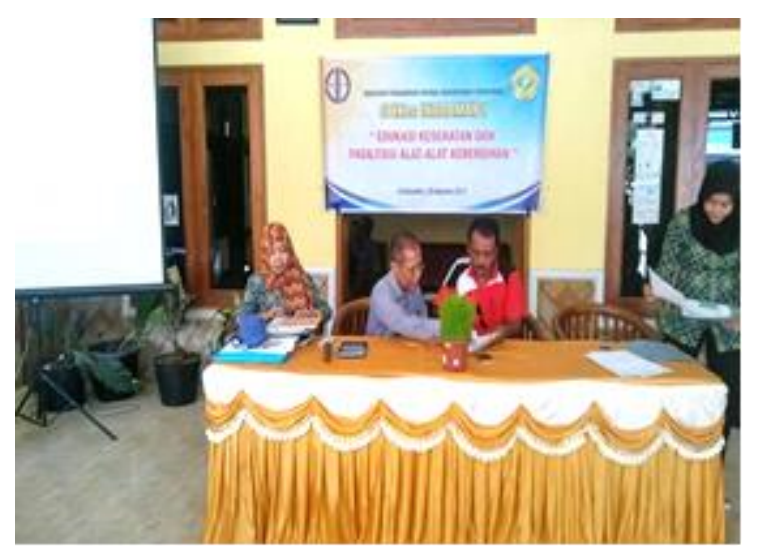

Gambar 3. Penandatanganan berita acara

Ibu dengan kehamilan risiko tinggi adalah ibu hamil yang mempunyai risiko atau bahaya yang lebih besar pada kehamilan/persalinan normal (Simarmata et al., 2014). Penurunan kematian ibu tidak dapat dilakukan hanya dengan mengatasi faktor penyebab langsung kematian ibu tetapi juga harus mengatasi faktor penyebab tidak langsung diantaranya kondisi sosial (pendidikan dan pekerjaan), keikutsertaan program Keluarga Berencana (KB), Keinginan untuk hamil dan kunjungan antenatal (Aeni, 2013). Oleh karena itu, beberapa upaya yang harus dilakukan untuk mencegah kehamilan risiko tinggi selain penyuluhan adalah peningkatan pelayanan antenatal, penurunan kehamilan remaja serta peningkatan cakupan peserta aktif KB (Bartini \& Mediastuti, 2017).

Upaya yang dilakukan WUS untuk mencegah kehamilan risiko tinggi yang disebabkan " 4 Terlalu" antara lain:

1. Terlalu Muda : tidak berencana untuk hamil apabila umur kurang dari 20 tahun karena organ reproduksi belum siap untuk dibuahi/belum matang sehingga dapat menggunakan alat kontrasepsi untuk mengatur kehamilan. Namun apabila sudah terjadi kehamilan, periksa secara rutin untuk deteksi dini kesejahteraan ibu dan janin.

2. Terlalu tua : apabila ibu sudah berumur lebih dari 35 tahun diharapkan tidak hamil lagi karena akan berisiko yang disebabkan alat reproduksi fungsinya kurang maksimal. Namun apabila masih terjadi kehamilan, periksa secara rutin untuk memantau keadaan ibu dan janin.

3. Terlalu dekat : untuk mencegah kehamilan yang terlalu dekat maka menggunakan alat kontrasepsi yang sesuai untuk mengatur jarak kelamilan.

4. Terlalu banyak : rencanakan jumlah anak tidak lebih dari 4 orang (Sari et al., 2014; Fajriana \& Buanasita, 2018).

\section{KESIMPULAN}

kegiatan pengabdian kepada masyarakat ini merupakan salah satu kegiatan rutin yang dilaksanakan oleh Dosen STIKes Indramayu untuk melaksanakan Tridharma perguruan tinggi dalam membantu program pemerintah P2WKSS untuk meningkatkan derajat kesehatan masyarakat. Dari kegiatan ini dapat meningkatkan pengetahuan WUS dalam upaya pencegahan kehamilan risiko tinggi sebagai salah satu upaya untuk mengurangi jumlah kematian ibu dan bayi yang disebabkan 4 terlalu.

\section{UCAPAN TERIMA KASIH}

Dalam pelaksanaan kegiatan pengabdian kepada masyarakat ini, penulis banyak mendapatkan dukungan dari berbagai pihak. Oleh karenanya dalam kesempatan ini penulis mengucapkan terima kasih yang sebesarbesarnya kepada STIKes Indramayu, Kepala Desa Juntiweden beserta jajarannya, tokoh masyarakat dan warga masyarakat yang antusias mengikuti kegiatan ini.

\section{REFERENSI}

Aeni, N. 2013. Faktor Risiko Kematian Ibu. 7(10):453-459. http://dx.doi.org/10.21109/kesmas.v7i10.4

Bartini, I., Mediastuti, F. 2017. Kemitraan Bidan dan BKKBN dalam Upaya Peningkatan Pelayanan 
Kontrasepsi di Daerah Istimewa Yogyakarta. Jurnal Ilmiah Bidan. 2(2):37-44.

Djamilah, Kartikawati, R. 2014. Dampak Perkawinan Anak di Indonesia. Jurnal Studi Pemuda. 3(1):116.

https://doi.org/10.22146/studipemudaugm. 32033

Fajriana, A., Buanasita, A. 2018. Faktor Risiko yang Berhubungan dengan Kejadian Bayi Berat Lahir Rendah di Kecamatan Semampir Surabaya. Media Gizi Indonesia. 13(1):71-80. http://dx.doi.org/10.20473/mgi.v13i1.71-80

Harianti, R., Nurbaiti. 2016. Karakteristik, Pengetahuan dan Sikap Pasangan Usia Subur tentang Penyakit Menular Seksual di Klinik " $Y$ " Kabupaten Indragiri Hulu. Jurnal Kesehatan Reproduksi.

7(3):199-209. http://dx.doi.org/10.22435/kespro.v7i3.6303. 199-209

Kamal, S.M.M. 2012. Decline in Child Marriage and Changes in Its Effect on Reproductive Outcomes in Bangladesh. Journal of Health, Population and Nutrition. 30(3):317-330. https://dx.doi.org/10.3329/jhpn.v30i3.12296

Kementerian Kesehatan Republik Indonesia. 2010. Riset Kesehatan Dasar Riskesdas 2010. Jakarta: Badan Penelitian dan Pengembangan Kesehatan Kementerian Kesehatan Republik Indonesia.

Monita, F., Suhaimi, D., Ernalia, Y. 2015. Hubungan Usia, Jarak Kelahiran dan Kadar Hemoglobin Ibu Hamil dengan Kejadian Berat Bayi Lahir Rendah di RSUD Arifin Achmad Provinsi Riau. JOM FK Universitas Riau. 2(2):1-17.

Nursal, D.G.A., Satri, R.M. 2014. Kehamilan Risiko Tinggi di Puskesmas Lubuk Gadang Kabupaten Solok Selatan. Jurnal Kesehatan Masyarakat Andalas (Andalas Journal of Public Health). 9(1):23-28. https://doi.org/10.24893/jkma.v9i1.414

Putri, G.N., Winarni, S., Dharmawan, Y. 2017. Gambaran Umur WUS Muda dan Faktor Risiko Kehamilan terhadap Komplikasi Persalinan atau Nifas di Kecamatan Bandungan Kabupaten Semarang. Jurnal Kesehatan Masyarakat. 5(1):150-157.

Ristrini, R., Oktarina, O. 2014. Effort to Enhance Early Detection for Vulnerable Pregnancy by
Midwives Through Complete Fulfillment of Maternal and Child Health (MCH) Bookin Bangkalan East Java Year 2013. Buletin Penelitian Sistem Kesehatan. 17(3):215-225.

Sari, P.H., Hapsari, D., Dharmayanti, I., Kusumawardani, N. 2014. Faktor-Faktor yang Berpengaruh Terhadap Risiko Kehamilan "4 Terlalu (4-T)" pada Wanita Usia 10-59 Tahun (Analisis Riskesdas 2010). Media Penelitian dan Pengembangan Kesehatan. 24(3):143-152.

Simarmata, O.S., Sudikno, S., Kristina, K., Bisara, D. 2014. Determinan Kejadian Komplikasi Persalinan di Indonesia: Analisis Data Sekunder Riset Kesehatan Dasar 2010. Jurnal Kesehatan Reproduksi. 5(3):1-14.

Sumarmi, S. 2017. Model Sosio Ekologi Perilaku Kesehatan dan Pendekatan Continuum of Care untuk Menurunkan Angka Kematian Ibu. The Indonesian Journal of Public Health. 12(1):129-141. http://dx.doi.org/10.20473/ijph.v12i1.2017.1 29-141

Wallach, E.E., Gindoff, P.R., Jewelewicz, R. 1986. Reproductive potential in the older woman. Fertility and Sterility. 46(6):989-1001. https://doi.org/10.1016/S00150282(16)49869-9 